\title{
日本昆虫学会会誌“Entomological Science”目次
}

\section{Vol. 19 No. 4}

(2016 年 10 月発行)

\section{Systematics}

Libin MA, Yang LIU and Yalin ZHANG. Revision for the swordtail cricket genus Homoeoxipha (Grylloidea:

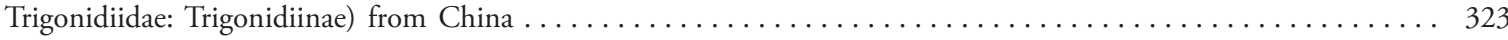

Natsuko I. KONDO, Ryuhei UENO, Kako OHBAYASHI, Veronika V. GOLYGINA and Kenzi TAKAMURA. DNA barcoding supports reclassification of Japanese Chironomus species (Diptera: Chironomidae) . . . . . . . . 337

Yûsuke N. MINOSHIMA. Taxonomic review of Agraphydrus from Japan (Coleoptera: Hydrophilidae:

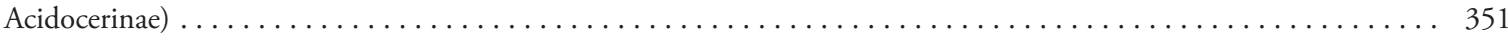

Anil Kumar DUBEY and Sudhir SINGH. Description of a new genus and species of whitefly (Hemiptera: Sternorrhyncha) infesting Rhynchosia minima (Fabaceae) in Karnataka, India . . . . . . . . . . . . . 367

Davide VALLOTTO, Joachim BRESSEEL, Jérôme CONSTANT and Marco GOTTARDO. Morphology of the terminalia of the stick insect Dajaca napolovi from Vietnam (Insecta: Phasmatodea) . . . . . . . . . . . . 376

Morphology, Histology and Fine Structure

Kosei HASHIMOTO, Koh SUZUKI and Fumio HAYASHI. Unique set of copulatory organs in mantises: Concealed female genital opening and extremely asymmetric male genitalia $\ldots \ldots \ldots \ldots \ldots \ldots \ldots$

Physiology and Biochemistry

Seiji TANAKA, Shinjiro SAEKI, Yudai NISHIDE, Ryohei SUGAHARA and Takahiro SHIOTSUKI. Body-color and behavioral responses by the mid-instar nymphs of the desert locust, Schistocerca gregaria (Orthoptera:

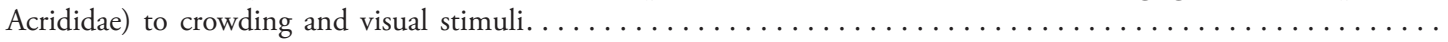

\section{Behavior}

Hiroshi YOROZUYA. Monitoring and characterization of DC electrical penetration graph waveforms of tea green

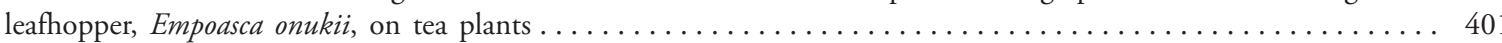

Adema BARRY and Kazuro OHNO. Cornicle secretions of Uroleucon nigrotuberculatum (Homoptera: Aphididae)

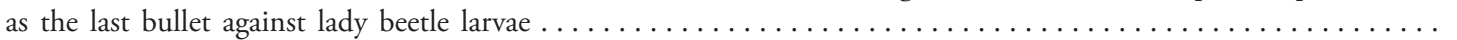

Ecology and Population Biology

Sinzo MASAKI, Masayuki SOMA, Hidenori UBUKATA, Haruo KATAKURA, Rie ICHIHASHI, Zhuqing HE, Nobuaki ICHIJÔ, Norio KOBAYASHI and Makio TAKEDA. Ground crickets singing in volcanic warm "islets" in snowy winter: Their seasonal life cycles, photoperiodic responses and origin $\ldots \ldots \ldots \ldots \ldots \ldots \ldots \ldots$

Kosei HASHIMOTO and Fumio HAYASHI. Cantharidin world on islands: Species diversity of canthariphilous

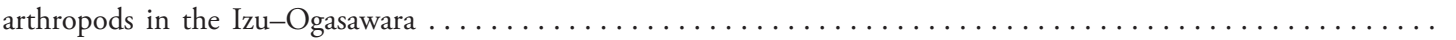

Short Communications

Shun'ichi MAKINO. Post-hibernation ovary development in queens of the Japanese giant hornet Vespa mandarinia

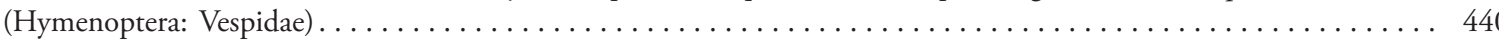

Tatsuya IDE, Natsumi KANZAKI, Wakako OHMURA, Yoko TAKEMATSU and Kimiko OKABE. Species status

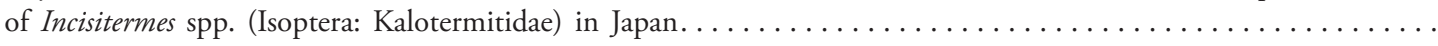

Munetoshi MARUYAMA, Takashi KOMATSU and Watana SAKCHOOWONG. Host record of the myrmecophilous carabid genus Cryptocephalomorpha (Coleoptera: Carabidae: Pseudomorphinae) with description of a new

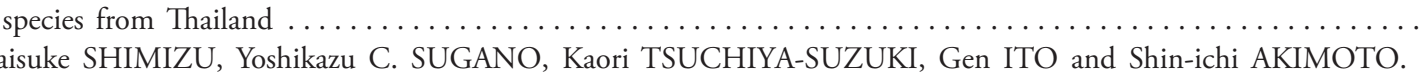
Dimorphism of right-left asymmetry in the female genitalia of the brachypterous grasshopper Parapodisma

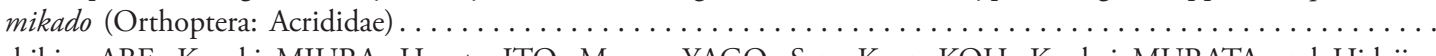

Yoshihisa ABE, Kazuki MIURA, Hayato ITO, Masaya YAGO, Sang-Kyun KOH, Kouhei MURATA and Hideji YAMASHITA. Origins of recently re-established and newly discovered populations of the endangered butterfly Shijimiaeoides divinus (Lepidoptera: Lycaenidae) in Oita Prefecture, Japan . . . . . . . . . . . . . . . . . .

Editorial

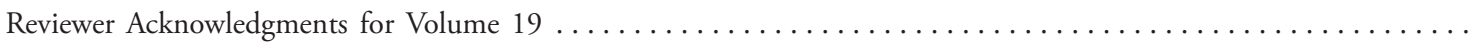

